\title{
Demand of ICT-based chemistry learning media in the disruptive era
}

Ratna Kumala Dewi, Sri Wardani, Nanik Wijayati, Woro Sumarni

Postgradute Program of Chemistry Education, Universitas Negeri Semarang, Indonesia

\begin{tabular}{|c|c|}
\hline Article Info & ABSTRACT \\
\hline Article history: & The challenges of education in the era of the industrial revolution include \\
\hline Received Feb 12, 2019 & $\begin{array}{l}\text { disruption } 4.0,21 \text { st-century skills, globalization, and global competition. } \\
\text { Chemistry is a subject that needs to be developed in order to improve the }\end{array}$ \\
\hline Revised Apr 15, 2019 & educational system in the era of disruption. The purpose of this research is to \\
\hline Accepted May 18, 2019 & $\begin{array}{l}\text { identify and analyze the needs of the media-based chemistry study ICT at } \\
\text { grade X redox materials in State Senior Highschool } 8 \text { Semarang during the }\end{array}$ \\
\hline Keywords: & $\begin{array}{l}\text { disruption. The method used in this research is a descriptive qualitative } \\
\text { method which consists of the study of literature and the study of the field. }\end{array}$ \\
\hline $\begin{array}{l}\text { Chemistry learning media } \\
\text { ICT } \\
\text { Redox material }\end{array}$ & $\begin{array}{l}\text { Method of data collection is done through observation, question form, } \\
\text { documentation, interview teachers, as well as interview students. This } \\
\text { research instrument consisting of a sheet of observation, question form, and } \\
\text { sheet interview. The results showed that chemical-based learning media }\end{array}$ \\
\hline Senior high school & $\begin{array}{l}\text { limited ICT in State Senior Highschool } 8 \text { Semarang redox materials } \\
\text { especially in class X. That is because of the teacher's difficulty in innovating } \\
\text { to develop learning media chemistry-based ICT and lack of student } \\
\text { understanding and literacy in the study of chemical materials. Teachers play } \\
\text { an important role in order to educate the students towards the era of } \\
\text { disruption. In this era of chemical subjects not only taught students with } \\
\text { literacy (reading, writing, math) but the need for a new form of literacy the } \\
\text { literacy data, technology, and human resources in order to overcome learning } \\
\text { difficulties and improving students learning outcomes for better value. }\end{array}$ \\
\hline
\end{tabular}

Copyright (C) 2019 Institute of Advanced Engineering and Science. All rights reserved.

\section{Corresponding Author:}

Woro Sumarni,

Chemistry Education, Postgraduate Program,

Universitas Negeri Semarang,

Kelud Utara III, Semarang 50237, Central Java, Indonesia.

Email:woro@mail.unnes.ac.id

\section{INTRODUCTION}

Education in Indonesia is facing challenges in the era of disruption. In the disruption era, there is an inequality or instability of the conventional education system into a technology-based education system [1]. Teachers and students are not yet fully able to adapt to the current education system. The Government appealed in order to reorganize the management and leadership of national and regional education, reorganized the curriculum, and reorganized the system construction of the learning in order the reconstruction of education in Indonesia. Important reconstruction was done so that the pace accelerated educational enhancement in the era of disruption. Curriculum education in the era of disruption needs to be developed with attention to the readiness and needs of the learners, the appropriateness of content, as well as the process of learning assessment [2].

Era technology disruption is a combination between the domains of physical, digital, and humans [3]. In this era of growing millennial generation who are experts in the field of technology [4]. Technology trends in the millennial generation of the industrial revolution 4.0 may include artificial intelligence, biotechnology, robotics, internet of things, and a driverless car. The countries in the world including 
Indonesia wanted an education that is relevant to the development of the industrial revolution era of 4.0 in order to become a productive citizen. The education system in Indonesia keeps pace with social and technological innovations in order to integrate digital literacy in the curriculum development in schools. Schools play an important role in designing various activities promoting aspects of multicultural students, entrepreneurship, blended learning, life-long learning, extracurricular, character building 4.0, e-learning, and global network for academic.

The challenges of education in the era of the industrial revolution include disruption 4.0, 21stcentury skills, globalization, and global competition [5]. Efforts in facing the challenges of the educational need for human resources development through literacy in order to face the new era of the industrial revolution 4.0 not only enough with the old literacy (reading, writing, math) as capital but learning the basics in need for new literacy developed in the form of literacy data, technology literacy, and literacy human resources [6].

Data literacy is the ability to read, analyze, and use information (big data) in the digital world. Technology literacy is an understanding of how machines work and the application of technology in the progress of science and technology [7]. While human literacy is the development of human resources in the fields of humanities, communication, and design [8]. Indonesia can face the challenges of globalization in the disruptive era and the 4.0 industrial revolution by producing quality education. One of the key factors in the success of education is in the teacher. In the current education system schools are important to invest in preparing professional teachers who are able to educate students towards a brighter future [9]. The teacher must develop competence as a facilitator and agent of change for students in addition to developing individual skills of students in the field of chemistry [10].

In order for graduates to be competitive in order to face the era of industrial revolution 4.0, teachers need to find methods to develop cognitive capacity by applying high-level thinking skills (HOTS), one of which is critical thinking skills [11]. The application of HOTS to chemical learning systems requires strategy and special learning models such as inquiry that is applied according to skills in the 21st century [12]. The era of industrial revolution 4.0 is closely related to 21 st-century skills. In 21 st century skills, innovation in learning media in chemistry is needed in order to increase student motivation and learning outcomes. Learning media innovation in the 21 st century requires skills in problem-solving, collaboration, communication, and critical thinking to create new things [13]. Critical thinking developed in 21 st-century skills is the ability to analyze, evaluate, convince, decide, and argue in deciding opinions [14].

The 21 st-century education skills are educational support systems that regulate the condition of students in learning, accommodate students' learning needs and support positive relationships between students through effective learning [15]. One technique in making effective and enjoyable learning is by utilizing technology and informatics (ICT) [16]. Information and Communication Technology is a very important thing in supporting the advancement of education today [17]. Technology is a means to develop learning material so that students are more interested in and passionate about learning [18]. Technology can be in the form of interactive learning media as stated in 21st-century skills [19].

Learning with computer-generated visualization such as multimedia has become a topic of major concern in recent years [20]. Multimedia can be in the form of e-learning which is a form of learning by utilizing electronic technology (radio, television, film, computers, and the internet) [21]. ICT-based learning such as e-learning in 21 st-century skills for chemistry subjects is closely related to student competencies such as collaboration, digital literacy, critical thinking, and problem-solving developed in the world of information and communication technology.

Chemistry is one of the natural sciences that study everything about the matter which includes structure, composition, dynamics, change, and energy which involves skill and reasoning [22]. Chemistry lessons in high school aim to enable students to understand basic theories, principles, concepts, and laws that are interrelated so that they are able to apply their knowledge in everyday life [23]. Chemistry subjects are theoretical and practical which require high-level thinking skills to be able to solve count problems and learning theories [24].

High-level thinking ability in chemistry subjects is one of them is on redox matter. Widati et al. Mentioned that redox material consists of changes in oxidation number, reaction equation based on increase and decrease in oxidation number, and redox application in daily life [25]. The purpose of this study was to identify and analyze the needs of ICT-based learning media in class X redox material in State Senior Highschool 8 Semarang.

\section{RESEARCH METHOD}

The research method used in this study is a qualitative descriptive method. The subjects in this study were students of class XI IPA 2 State Senior Highschool 8 Semarang academic year numbered 2018/2019.

Int. J. Eval. \& Res. Educ. Vol. 8, No. 2, June 2019: 265 - 270 
The data analysis technique in this study was the analysis of daily test scores on redox material, questionnaires, and direct communication techniques with teachers and students through interviews. Data collection is done by observation, questionnaire, interview, and documentation.

Retrieval of students' daily test value data at class $\mathrm{X}$ on redox material was used to determine students' cognitive learning outcomes. Questionnaires in this study contain 20 questions about the redox material that is distributed to students who are the subjects in this study, namely class XI IPA 2. A questionnaire is used to analyze the learning media needs in school. Teacher interviews were conducted to one of the chemistry teachers at State Senior Highschool 8 Semarang to get results in the form of solutions and efforts to overcome students' difficulties in the redox material in class X through ICT-based learning media. Student interviews are used to question students' difficulties in learning, especially in redox material. Documentation is used to support research in the form of photographs when learning activities take place in the classroom.

\section{RESULTS AND DISCUSSION}

This research was conducted in State Senior Highschool 8 Semarang in August 2018 in class XI $2018 / 2019$ school year. The research was started by giving a research permit to the vice principal of the student field. The data analysis technique in this study uses descriptive qualitative, namely by analyzing the daily test scores of students on redox subjects, analysis of student response questionnaires, teacher interviews and student interviews and analysis based on observations and documentation.

Analysis of cognitive learning outcomes was carried out by retrieving students' daily test value data on redox material during class X. Daily results of students of class X-A redox material up to class X-I in State Senior Highschool 8 Semarang showed that many students were still below KKM (Minimum Completion Criteria). This shows that many students still have difficulty understanding redox material. Calculation of students' daily test scores can be seen in Table 1.

Table 1. Analysis of student daily test values

\begin{tabular}{|c|c|c|c|c|c|c|c|c|c|}
\hline \multicolumn{10}{|c|}{ Class } \\
\hline & XA & $\mathrm{XB}$ & $\mathrm{XC}$ & $\mathrm{XD}$ & $\mathrm{XE}$ & $\mathrm{XF}$ & $\mathrm{XG}$ & $\mathrm{XH}$ & XI \\
\hline Score & 2705 & 2195 & 2210 & 2230 & 2140 & 2165 & 2700 & 2300 & 2250 \\
\hline Average & 75.13889 & 60.97222 & 61.38889 & 61.94444 & 59.44444 & 60.13889 & 75 & 63.88889 & 62.5 \\
\hline Criteria & Complete & Incomplete & Incomplete & Incomplete & Incomplete & Incomplete & Complete & Incomplete & Incomplete \\
\hline
\end{tabular}

In Table 1 it can be seen that of the 9 classes in class $\mathrm{X}$ only two classes had average mastery learning above KKM while the other six classes were still below the KKM. This is due to students' learning difficulties in redox material.

Students 'difficulties in redox material occur because of a lack of students' understanding in learning redox material including distinguishing the meaning of oxidation and reduction reactions, equating reactions using oxidation numbers and half-reaction methods, and determining oxidation numbers in a compound. Students have difficulty understanding the material because the material taught by the teacher is abstract, there is no other literature provided by the teacher other than the textbook in the library. In addition, the things that cause difficulties for students in redox material are that students easily forget the material, are not careful and do not pay attention to the teacher when teaching. Solutions to overcome student difficulties can be done by providing technology-based interactive learning such as e-learning. E-learning based learning models can facilitate students in the learning process and make students enthusiastic to learn learning material, especially redox material [25].

Based Analysis Questionnaire contains questions to understand students' difficulties in redox material. The results of the questionnaire responses of students to redox subjects indicate that students experience difficulties in redox material, especially in resolving the reaction equation with the oxidation method, equalizing the redox reaction in an acidic atmosphere and alkaline atmosphere, and equating the redox reaction with the half-reaction method.

Factors that cause student difficulties in redox material are divided into two, namely internal factors and external factors. Internal factors include students who are less prepared to receive lessons, students pay less attention to the teacher in the learning process, there is no literature that students have because the books are only loaned from the library. In addition, external factors can be in the form of a learning media classroom environment, as well as student learning motivation which is also an important factor in learning success. Student learning motivation can be improved by the presence of ICT-based interactive learning media such as e-learning [26]. Students with various backgrounds must be able to work and study with 
different environments (teamwork), thematic studies with various disciplines, accompanying teachers, and extracurricular activities to support chemical learning in schools [27].

Based on student interviews, the results show that redox material is material that is quite difficult for students. Errors and misunderstandings of students in redox material result in not achieving learning objectives. Students at State Senior High School 8 Semarang have been able to use computers to search for chemical subject data through online networks such as e-learning. The e-learning application allows students to do their assignments whenever and wherever they want [28]. Social networking sites, blogs, wikipedia, google, youtube, smartphone, web, and e-modules can complement learning media in the classroom in addition to supporting books. The media for ICT-based learning applications can become new learning tools and important needs in the education sector [29].

Based on the teacher's interview, the results showed that the chemistry teacher had taught at State High School 8 Semarang for more than 20 years. Learning media that are usually used are library books and powerpoint presentations. The teacher has been given training in ICT-based learning at the school. But if you make a new application the teacher has not been able to. If e-learning-based learning takes effect, chemistry teachers at State Senior High School 8 Semarang will begin to adapt to new learning media to improve current educational progress.

Principles that must be held by teachers in the disruptive era include push beyond comfort zone, work toward well defined, specific goals (work with clear targets or achievements according to learning goals), focus intently on impactful activities (focus on providing activities that meaningful and impact on students), receive and respond to high quality (receive and provide quality feedback for students), and develop a mental model of expertise (forming the mentality of students into the model of an expert).

The analysis of the needs of learning media in State Senior Highschool 8 Semarang is done by observing the condition of the class and school. State Senior High School 8 Semarang has prepared itself for ICT-based schools including supporting facilities such as wifi, LCD, projector, computer lab, sound system, and laptop for each teacher. Each teacher has also been given IT-based learning training. The teacher has been able to create and present learning media in the form of powerpoints but when creating new applications such as the web, flash, the teacher's e-module cannot. To improve 21 st-century education skills in the era of disruption teachers can work with application makers to create e-learning-based interactive learning media [30]. When viewed from the technological advances of students at State Senior High School 8 Semarang, they are able to use IT such as learning with internet or web technology, social media, and smartphones. In Figure 1 shows student learning space accompanied by learning media that support the implementation of e-learning.

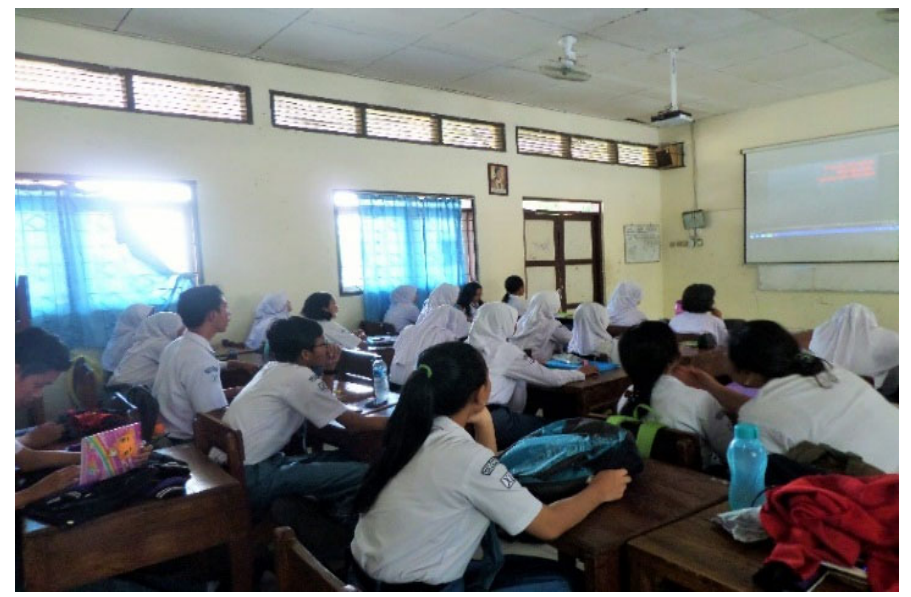

Figure 1. The condition of learning media in classes

Schools need to make several efforts in order to face challenges in the disruption era such as developing critical and creative thinking skills, revising student assessment systems, developing curriculum, and prioritizing learning processes rather than learning outcomes [31]. The education system in the 21stcentury must be equipped with technology and information that is more creative and innovative and more advanced and ready to be competitive [15]. Teachers are given guidance and information regarding the use of

Int. J. Eval. \& Res. Educ. Vol. 8, No. 2, June 2019: 265 - 270 
technology in schools to be safe and effective. The first step the teacher can use social media in communicating and teaching chemistry learning such as youtube, facebook, blog, encyclopedia, and so forth. Through social media teachers and students will be directly connected to communicate with each other and introduce more interesting chemical concepts [32].

The new transformation of the world of education in the era of disruption can include learning models that emphasize high-level thinking skills (HOTS), technology-based learning media (ICT), and the integration of digital literacy in curriculum development systems [33]. Through digital literacy school assignments can be done anytime and anywhere by utilizing information technology [34]. State Senior High School 8 Semarang has sought to improve the quality of education in the disruptive era. Schools and teachers have an important role in producing graduates who are able to face an era of disruption or instability [35]. The teacher can provide students with creative and innovative knowledge of chemistry subjects [36]. The teacher acts as an agent of change in improving student literacy in the fields of data literacy, technology literacy, and HR literacy. It is expected that the era of disruption of students can adapt more quickly so that the chemical learning process can run well through e-learning based learning media.

\section{CONCLUSION}

State Senior Highschool 8 Semarang is a suburban school category but this school has developed and complements supporting facilities in the learning process. Strategies in dealing with disruptive eras can be done by developing digital skills for teachers and students, teachers try and apply new technologies in the field of chemical learning media, the application of new literacy in the form of data, technologyliteracy, and collaboration of all school components consisting of principals, teachers, and students to support the achievement of the advancement of the education system in 21 st-century skills. Learning chemistry at Semarang 8 High School can be improved by applying ICT-based chemical learning media such as elearning. E-learning based chemistry learning can be online learning through the web, encyclopedia, blogs, social media, e-modules etc. State Senior Highschool 8 Semarang has prepared supporting facilities and infrastructure so that there are no obstacles when e-learning based chemistry learning is applied. E-learning based chemistry learning can be applied to redox material to overcome learning difficulties in students and increase learning motivation in order to obtain better value.

\section{ACKNOWLEDGEMENTS}

The author would like to say thank to Mr. Cepi Kurniawan, $\mathrm{PhD}$ for his advice, students and teachers of State Senior Highschool 8 Semarang who have voluntarily become the subjects in this study.

\section{REFERENCES}

[1] D. Ivanov, A. Dolgui, B. Sokolov, \& A. Dolgui, "The impact of digital technology and Industry 4 . 0 on the ripple effect and supply chain risk analytics," Int. J. Prod. Res., vol. 0(0), pp. 1-18, 2018.

[2] J. Shilpa., "New Media Technology in Education - a Genre of Outreach Learning," Glob. Media Journal-Indian Ed., vol. 5(1), pp. 1-11, 2014.

[3] E. Ospennikova, M. Ershov, \& I. Iljin., "Educational Robotics as an Inovative Educational Technology," Procedia Soc. Behav. Sci., vol. 214(June), pp. 18-26, 2015.

[4] M. A. Peters., "Technological unemployment: Educating for the fourth industrial revolution," Educ. Philos. Theory, vol. 49(1), pp. 1-6, 2017.

[5] J. W. Rojewski and R. B. Hill., "A Framework for 21st-Century Career-Technical and Workforce Education Curricula," Peabody J. Educ., vol. 92(2), pp. 180-191, 2017.

[6] A. Gutiérrez-Martín and K. Tyner., "Media \{Education\}, \{Media $\}\{$ Literacy\} and \{Digital\} $\{$ Competence\}," Comunicar, vol. 19(38), pp. 31-39, 2012.

[7] A. Y. L. Lee., Media education in the School 2.0 era: Teaching media literacy through laptop computers and iPads. Glob. Media China, 2016.

[8] R. Schneider., "Research Data Literacy," Commun. Comput. Inf. Sci, vol. 397 CCIS(October), pp. 134-140, 2013.

[9] H. B. Boholano., "Smart social networking: 21st century teaching and learning skills," Res. Pedagog, vol. 7(1), pp. 21-29, 2017.

[10] T. Hadinugrahaningsih, Y. Rahmawati, \& A. Ridwan., "Developing 21st century skills in chemistry classrooms: Opportunities and challenges of STEAM integration," AIP Conf. Proc, vol. 1868, 2017.

[11] W. Wartono, M. N. Hudha, \& J. R. Batlolona., "How are the physics critical thinking skills of the students taught by using inquiry-discovery through empirical and theorethical overview?," Eurasia J. Math. Sci. Technol. Educ, vol. 14(2), 2018

[12] M. Hugerat and N. Kortam., "Improving higher order thinking skills among freshmen by teaching science through inquiry," Eurasia J. Math. Sci. Technol. Educ, vol. 10(5), pp. 447-454, 2014. 
[13] A.-N. Lay and K. Osman., "Developing 21st Century Chemistry Learning through Designing Digital Games," $J$. Educ. Sci. Environ. Heal, vol. 4(1), pp. 81-92, 2018.

[14] F. Erika and B. K. Prahani., "Innovative Chemistry Learning Model to Improve Argumentation Skills and SelfEfficacy," IOSR J. Res. Method Educ, vol. 07(01), pp. 62-68, 2017.

[15] C. P. Dwyer, M. J. Hogan, \& I. Stewart., "An integrated critical thinking framework for the 21 st century," Think. Ski. Creat, vol. 12, pp. 43-52, 2014.

[16] S. Livingstone., "Critical reflections on the benefits of ICT in education," Oxford Rev. Educ, vol. 38(1), pp. 9-24, 2012.

[17] J. S. Fu., "ICT in education: A critical literature review and its implications," Int. J. Educ. Dev. Using Inf. Commun. Technol, vol. 9(1), pp. 112, 2013.

[18] S.-K. Shin., "Teaching Critical, Ethical and Safe Use of Ict in Pre-Service Teacher Education," Lang. Learn. Technol, vol. 19(191), pp. 181-197, 2015.

[19] A.-N. Lay and K. Osman., "Developing 21st Century Chemistry Learning through Designing Digital Games," $J$. Educ. Sci. Environ. Heal, 2018.

[20] R. M. Rias and H. B. Zaman., "Understanding the role of prior knowledge in a multimedia learning application," Australas. J. Educ. Technol, vol. 29(4), pp. 537-548, 2013.

[21] M. Aparicio, F. Bacao, \& T. Oliveira., An e-learning theoretical framework. Educ. Technol. Soc, 2016.

[22] M. Tuysuz, B. Ekiz, O. Bektas, E. Uzuntiryaki, \& A. Tarkin., "Pre-service chemistry teachers' understanding of phase changes and dissolution at macroscopic , symbolic , and microscopic levels," Procedia - Soc. Behav. Sci, vol. 15, pp. 452-455, 2011.

[23] T. Gupta, K. A. Burke, A. Mehta, \& T. J. Greenbowe., "Impact of guided-inquiry-based instruction with a writing and reflection emphasis on chemistry students' critical thinking abilities," J. Chem. Educ, vol. 92(1), pp. 32-38, 2015.

[24] I. N. Selamat., "Students ' Critical Thinking Skills in Chemistry Learning Using Local Culture-Based 7E Learning Cycle Model," Int. J. I, vol. 11(2), pp. 399-412, 2018.

[25] H. R. Widarti, A. Permanasari, \& S. Mulyani., "Student misconception on redox titration (A challenge on the course implementation through cognitive dissonance based on the multiple representations)," J. Pendidik. IPA Indones., vol. 5(1), pp. 56-62, 2016.

[26] K. M. Y. Law, V. C. S. Lee, and Y. T. Yu, "Learning motivation in e-learning facilitated computer programming courses," Comput. Educ., vol. 55, no. 1, pp. 218-228, 2010.

[27] A. Ferouni, A. Khyati, M. Talbi, S. El Jamali, \& M. Radid, "Identification of a Few Difficulties in Chemistry in Moroccans High School: Case of the Redox," Procedia - Soc. Behav. Sci., vol. 46, pp. 101-107, 2012.

[28] W. Bhuasiri, O. Xaymoungkhoun, H. Zo, J. J. Rho, \& A. P. Ciganek., Critical success factors for e-learning in developing countries: A comparative analysis between ICT experts and faculty. Comput. Educ, 2012.

[29] M.-H. Lin., "A Study of the Effects of Digital Learning on Learning Motivation and Learning Outcome," EURASIA J. Math. Sci. Technol. Educ, vol. 13(7), pp. 3553-3564, 2017.

[30] S. B. Heilesen and J. Josephsen., E-learning: Between augmentation and disruption?. Comput. Educ, 2008.

[31] J. P. L. Tan, S. S. Choo, T. Kang, \& G. A. D. Liem., "Educating for twenty-first century competencies and futureready learners: research perspectives from Singapore," Asia Pacific J. Educ., vol. 37(4), pp. 425-436, 2017.

[32] M. Henderson, I. Snyder, \& D. Beale., "Social Media for Collaborative Learning: a Review of School Literature," Aust. Educ. Comput., vol. 28(2), 2013.

[33] B. D. Jones., "Motivating Students to Engage in Learning: The MUSIC Model of Academic Motivation," Int. J. Teach. Learn. High. Educ., vol. 21(2), pp. 272-285, 2009.

[34] M. Pischetola and U. Cattolica., "A Research on Sustainable Local Empowerment Digital Media and Learning Evolution," Glob. Media J., vol. 11(18), pp. 1-12, 2011.

[35] P. Seet and J. Jones., The Fourth Industrial Revolution : the implications of technological disruption for Australian VET.

[36] I. V. Tetko, O. Engkvist, U. Koch, J. L. Reymond, \& H. Chen., "BIGCHEM: Challenges and Opportunities for Big Data Analysis in Chemistry," Mol. Inform., vol. 35(11-12), pp. 615-621, 2016.

Int. J. Eval. \& Res. Educ. Vol. 8, No. 2, June 2019: 265 - 270 